\title{
The Origin of Limestones.
}

I IMESTONE takes high rank among those common things the proper understanding of which leads one into a wide circle of the sciences. In a British Association lecture at Norwich in I 868 "On a piece of chalk," Huxley declared that any one who acquired a knowledge of the history of a piece of chalk had a far truer conception of the universe, and man's relation to it, than one wellread in human records and ignorant of those of Nature. This statement by Huxley concerning a piece of chalk applies with added force to the natural history and uses of limestones as a whole; for it should be emphasised that the use of limestone contributes very largely, and in ways too numerous to mention, to the well-being of civilised communities. It was therefore fitting that, in his recent presidential address to the Washington Academy of Sciences (Journal, I924, vol. I4, No. I4), Dr. $\mathrm{T}$. W. Vaughan gave a prominent place to a consideration of the origin of limestones.

Limestones occur among the sedimentary rocks, and must have been comparatively scarce, in the bedded form in which we know them, during the early stratigraphical history of the earth. R. A. Daly, indeed, thinks that the ocean-waters of preCambrian times were limeless, and to that condition attributes the absence of fossil remains of calcareous organisms in strata of pre-Cambrian age. It is more probable, however, that any precipitation of calcium carbonate that took place in the earth's primeval ocean-waters left the ocean far from limeless; and it seems more reasonable to attribute the absence of calcareous fossil remains in pre-Cambrian strata either to the evolution time-factor, or to metamorphism of the limestone, rather than to the limeless condition of pre-Cambrian ocean-waters.

Igneous rocks represent the ultimate source from which the lime now found in limestones has been largely derived. The average igneous rock of the earth's crust contains about 5 per cent. of lime. The disintegration of rocks by atmospheric agents is accompanied by the solution of the lime in surface waters, chiefly as bicarbonate and sulphate. The precipitation of calcium carbonate in the sea is effected chiefly by the action of calcareous organisms such as foraminifera (especially globigerina), corals, molluscs, and calcareous algæ.

The importance of globigerina as limestone builders was amply proved by the Challenger Expedition, from the results of which it was estimated that globigerina ooze covers an area of about 50 million square miles of the ocean floor, i.e. about a quarter of the total surface of the earth. The globigerina ooze passes gradually at greater depth into the redclay deposits which also cover an area of about 50 million square miles. The globigerina ooze itself contains on an average only about 65 per cent. of calcium carbonate, and incorporates within itself a considerable amount of " colloidal mud" similar in character to the red clay of greater depths. Dr. Vaughan enumerates four sources from any or all of which this " colloidal mud" of globigerina ooze and other oceanic deposits may be derived, namely, (I) outwash from the land; (2) volcanic and other dust precipitated from the atmosphere; (3) the residue from the tests of dead pelagic organisms after these tests have been more or less completely dissolved while falling to the bottom; and (4) the mineral residue from the decomposed' soft parts of organisms, some of which may be plankton.

Recent analyses of bottom samples of globigerina ooze collected off the American coasts show that the percentage of calcium carbonate decreases as the depth increases, a fact established previously, in a general way, by the work of the Challenger Expedition. The rule is not invariable, however; for, as shown by $\mathrm{J}$. Chumley in a recently published paper (Trans. Roy. Soc. Edin., I924, vol. 54, pt. I), the amount of calcium carbonate increases with the depth in some areas. In this connexion, Dr. Vaughan emphasises the fact that limestone of a high degree of purity, containing 95 per cent. or more of calcium carbonate, is usually formed either in shallow or only moderately deep water, and states that the purest limestone is deposited in very shallow water. The statements made in some text-books to the effect that globigerina ooze consists of pure calcium carbonate, and that pure limestone is a deep-sea deposit, are misleading.

The degree of purity of shoal-water limestones depends on the amount of outwash from the land. Where there is no outwash of terrigenous material, a beach deposit may contain more than 95 per cent. of calcium carbonate. The oolites of Key West and the Bahamas, which have been formed in shallow water, contain more than 99 per cent. of calcium carbonate. According to Dr. Vaughan, none of the deep-sea oozes approximate to this degree of purity; but J. Chumley records in one instance 97 per cent. at a depth of 2492 fathoms.

Pure shoal-water limestones appear to be chemical precipitates. They are deposited extensively as particles of " colloidal " size in the vicinity of Florida Keys, where storms give rise to a milky appearance in the water, due to the stirring up of the calcareous precipitate. The calcareous matter of the precipitate consists chiefly of fine particles and aggregates of aragonite. Some coarser foraminifera and molluscan shelly matter are present, but it is characterised chiefly by its minute acicular crystals of aragonite.

Such chemically precipitated calcium carbonate is formed only under peculiar conditions. It is deposited in shallow and relatively stagnant water which is at times heated by the sun above the normal temperature of the freely circulating ocean-water. A sample of water from the west side of Andros Island, Bahamas, showed a salinity more than two parts per thousand higher than that of the normal oceanwater of the region; and there is a considerable amount of organic matter in the mud. An analysis by E. T. Erickson of the calcareous mud at this locality showed the presence of 89.62 per cent. of calcium carbonate, I.39 of magnesium carbonate, 0.93 of strontium carbonate, and 0.68 of calcium sulphate. The presence of such a considerable amount of strontia $(0.63$ per cent.) is a feature worthy of special mention.

Efforts have been made by various workers to prove that the calcareous muds of Florida Keys, and other such deposits, have been precipitated by the action of bacteria. The investigations of Drs. G. H. Drew, K. F. Kellerman, and N. R. Smith appear to have established the fact that bacteria are present and very active in the muds of the Great Bahamas Bank and Florida Keys. These bacteria include Pseudomonas calcis, which is denitrifying in its action, and vibrios, some of which are strong ammonifiers, the latter being regarded as the more important as agents of precipitation. Dr. Smith inferred from his elaborate investigations that calcium carbonate is formed from calcium sulphate as a result of the growth of bacteria; and that calcium carbonate is formed in natural sea-water by pure cultures if organic matter is added.

NO. 2872 , VOL. I I 4 ] 
It seems reasonable to admit, as Dr. Vaughan does, that the association of ammonifying bacteria with others producing carbon dioxide may result in the formation of ammonium carbonate, which, reacting with calcium sulphate in solution, causes the precipitation of calcium carbonate. Dr. Vaughan points out, however, that the surface layer of oceanwater in tropical and subtropical regions is saturated with calcium carbonate, and that evaporation during the summer months is sufficient to account for the precipitation of calcium carbonate, without the agency of bacteria. Taking the evidence as a whole it seems legitimate to infer that, although bacterial precipitation is possible, it is quite unimportant as a cause of deposition of calcium carbonate even under the most favourable conditions, and that bacteria cannot compare with foraminifera, corals, molluscs, and nullipores as limestone builders. THOMAs CROOK.

\section{The German Scientific and Medical Association Meeting at Innsbruck.}

THE German Scientific and Medical Association -Gesellschaft deutscher Naturforscher und Ärzte-held its eighty-eighth meeting in Innsbruck, Austria, on September 2I-27. Many former members are now technically foreigners, domiciled in places once Germany, now called by other names. Hence a curious sort of superimposed internationality on a German-speaking basis, a formal recognition of foreign members, and a need for passports. The Austrian embassies and consulates offered visas free of charge from Berlin, Rome, Prague, Belgrade, Budapest, Buckarest, Bern, Danzig, Copenhagen, Stockholm and Christiania. A very emphatic welcome was given in Innsbruck by the Austrian President, Dr. Hainisch, in the name of the republic, and by Dr. Schneider, Minister of Education, for the Government and by others. There were more than 7000 ticket-holders, including a very few Englishmen, among whom were Prof. G. H. Hardy from Oxford and Prof. G. Barger of Edinburgh. The organisation arrangements seemed excellent. The programme was a pamphlet of 24 quarto pages with a very long list of papers, well cross-referenced to joint sessions, and mutual invitations between the 33 separate sections. The ground covered was similar to that of a British Association plus a British Medical Association meeting. The professors of the University of Innsbruck have fitly inaugurated their new buildings. All who co-operated with them, not forgetting the schoolboys who handed out programmes or wore ribbons and met travellers at the station, are to be congratulated highly on the success of their efforts.

The more popular addresses, corresponding to British Association evening lectures, were taken on the first three mornings of the week. These included Dr. Penck on the aspect of the Alps, Dr. Sommerfeld and others on the Bohr atom model, Dr. Porsch on the pollination of flowers by birds, and Dr. von Frisch on the senses and "language" of bees. Experiments have been made in training bees to feed on coloured paper. They appear to recognise colours, including violet, but scarlet is as black to them. The flower-birds visit bird-flowers with the same range of colours as their own plumage; these include red, yellow, and blue. Dr. Knoll has been watching the humming-bird hawk-moth by a proboscis-track method. He finds that after visiting one flower it leaves tiny traces of sugar water on the next object it touches. Dr. Frisch has follower the bees more exactly in an observation hive where each separate insect was marked and numbered consecutively. He says that bees finding honey report their luck to the hive by a special waddling dance. Their comrades are then stimulated to go out and hunt for flowers with the same scent as the honey brought home.

Among numerous communications to the sections were papers on cellulose, the rôle of alkaloids in the life of plants, sweet taste and chemical constitution, fractional distillation and the non-separation of chlorine isotopes, electrolytic conduction in molten alloys, the fine structure of fibre stuffs, on cyanamides, cyanogen compounds, the electric iron industry in the Tyrol, rapid telegraphy in ocean cables, the Siemens band-microphone, electric conductivity in rock salt and calc spar at high temperatures, quantitative spectrum analysis, the measurement from aeroplanes of radioactive decay products in the air, the formation of nitric oxide in the electric arc, the structure of the earth at different depths deduced from earthquake wave velocities, earth currents in mountains, deformation of individual crystals, microchemical detection of complex iron compounds in living plant tissues, and so on.

A joint meeting of Section I., Mathematics, and Section XV., Mathematical and Scientific Instruction, has considered the Denkschrift (Memorandum) of the Prussian Ministry of Education on the reorganisation of higher school education in Prussia. The Union of German Mathematical Societies and the German Committee for Mathematical and Scientific Instruction have also assisted. The hours allotted to mathematics and science, out of a weekly total of 29 , are, in the higher forms of the Gymnasium, 3 and 2 ; in the Real-Gymnasium, 3 and 4 ; in the Reform-real-gymnasium, 3 and 3 . A minimum of 4 hours weekly for mathematics is demanded. Since the days of Kant, a Weltanschauung without mathematics is impossible ; it is a training in conscientiousness and fidelity in detail. Science is not merely necessary for all higher specialised work, but is a necessary element of culture. It is a discussion about hours in the curriculum such as we knew in England a generation ago. In Berlin the history teachers are also perturbed about the Memorandum. It is a matter of rescuing humanity in the largest sense from the humanities in their narrowest meaning. Both aims and methods in education need humanising.

The interest of the meeting was intensified by simultaneous gatherings of other societies in association with particular sections. Such were the German Mathematikervereinigung, the Gesellschaft für angewandte Mathematik und Mechanik, the Gesellschaft für Epidemiologie, the Kolloid-Gesellschaft, the Gesellschaft für Kinderheilkunde.

A long series of excursions, especially for geographers and geologists, had been arranged for the days before and after the meeting. For some of these, early notice had to be given, as numbers were limited and clear instructions necessary- " only for good walkers . . . 7 hours a day ... bring food .. climbing boots . . . hotel meals only in evening perhaps only hay-shed."

There were several exhibitions, the exhibits being chiefly by German and Austrian firms, a large collection of new scientific books, scientific and medical apparatus especially for Röntgen rays and synthetic drugs. The schools showed some exceptionally good geometrical drawing, a subject to which great importance is attached. The most attractive exhibit was a film showing the movements of growing plants by the Badische Anilin- und Soda-Fabrik. Photo-

NO. 2872 , VOL. I I 4$]$ 